\title{
An Examination of the Various Ways Teachers Become Leaders: A Blended Process
}

\author{
Anthony Stephan Bundy (Corresponding Author) \\ Department of Educational Leadership and Professional Studies \\ William Paterson University, United States \\ E-mail: asbundyedd@gmail.com \\ Kevin J. Walsh \\ Department of Educational Leadership and Professional Studies \\ William Paterson University, United States \\ E-mail: Department of Educational Leadership and Professional Studies \\ William Paterson University, United States \\ E-mail:walsh@wpunj.edu \\ Geraldine Mongillo \\ Department of Educational Leadership and Professional Studies \\ William Paterson University, United States \\ E-mail: mongillog@wpunj.edu
}

Received: July 7, 2015 Accepted: July 17, 2015 Published: August 8, 2015

doi:10.5296/jet.v2i2.7968 URL: http://dx.doi.org/10.5296/jet.v2i2.7968

\begin{abstract}
The purpose of this exploratory study was to identify leadership factors that teachers viewed as most influential in their development as teacher leaders, and to generate suggestions to assist in the selection and cultivation of teacher leaders. This research employed a small sample of six teachers who were pursuing leadership roles and were identified as teacher leaders within their respective schools. Data collection was conducted through structured interviews, review of school documents, and a survey instrument. Teachers' interview data were coded based on key teacher leader qualities and behavioral characteristics identified in current literature. Analysis and subsequent findings concluded that teacher leader development is a blended process involving multiple key factors such as: self-reflection, teacher expertise, student-advocacy, professional development experiences, organizational empowerment for teachers, opportunities for job embedded collaboration with peers, teacher passion, and vision.
\end{abstract}

Keywords: Teacher Leaders, Educational Leadership, Development 


\section{Introduction}

The importance of teacher leadership in promoting the success of students in schools has been evidenced in articles, books, published studies, and through common practice in schools. However, there has been little consensus regarding the specific factors which actually lead to the development of teacher leaders (Metzgar, 2008; Bond, 2011). This study sought to identify those factors and experiences teachers view as most influential to their development as teacher leaders. This study's framework references the works of Hunzicker (2012), Danielson (2007), and Lieberman \& Friedrich (2010). Based on works of these three authors, eight factors were identified and utilized in the current study. They included: 1) professional development, 2) student-advocacy, 3) job-embedded collaboration 4) organizational empowerment, 5) teacher expertise, 6) passion, 7) vision, and 8) self-reflection.

This qualitative study used grounded theory methods (Krathwohl, 2009) and included a small sampling of teacher participants $(\mathrm{N}=6)$ who aspired to leadership roles in schools. All participants viewed themselves as teacher leaders as a result of either being formally assigned positions in their schools or viewed informally as leaders because of their willingness to carry out additional activities beyond the classroom. The current study was designed in a similar fashion to a small group study conducted by Hunzicker (2012) with eight elementary teachers.

\section{Literature Review and Conceptual Framework}

An initial review of the literature revealed several key factors related to teacher leadership development. The following literature review will expand on the eight identified factors related to leadership development. Professional development, student advocacy, job-embedded collaboration, were reflected in Hunzicker's (2012) study. Danielson (2007) suggested two additional factors of organizational empowerment and teacher expertise. Finally, Lieberman \& Friedrich (2010) add the factors of passion, vision, and self-reflection.

Nesbit, DiBiase, Miller, and Wallace (2001) identified two factors as influential in supporting the development of teacher leadership: a) leadership activities that were based within the context of existing professional development programs; and b) professional development activities taken through the independent actions of teachers toward their own self-improvement or the improvement of others. Two examples of teacher behaviors associated with successful participation in both types of professional development activities would be the demonstration of a desire to actively participate in professional development (Hunzicker, 2012) and taking the initiative to plan, implement, and lead professional development activities in schools or districts.

Hunzicker (2012), in her study on teacher leadership, also linked the concept of teacher self-efficacy with student-advocacy. Hunzicker described teacher self-efficacy as the teacher's ability to demonstrate effective decision making skills and gain confidence while conducting school related activities. "As they experience success, self-efficacy increases, creating an upward spiral that sustains motivation and elevates self-confidence... [t]eachers increased their self-efficacy by employing student-centered instructional approaches" (p.276). 
Hunzicker noted the strong relationship existing between teacher efficacy and student advocacy. The teachers' willingness to be an advocate for student success through their participation in building activities was influential in teachers making effective decisions and viewing themselves as leaders. There appears to be a distinct link between teacher self-efficacy and student-advocacy.

The aspect of teacher leadership identified as job embedded collaboration focused on those formal and informal occasions that provided teacher leaders with the opportunity to work collaboratively with their peers, in an effort to improve their colleagues' instructional abilities in the classroom (Hunzicker, 2012). This concept also was reflected in the types of leadership approaches and relationships found in school learning communities (Danielson, 2007). Examples of formal teacher leader roles are department chair, master teacher, and instructional coach. The process for gaining this type of teacher leader role is characterized by the teacher applying for the position, going through the selection process, and subsequently receiving training for the new position when chosen.

Informal teacher leader roles develop from the general consensus about an individual which results in the individual rising from the teacher ranks. Bond (2011) noted, "Instead of being selected, they voluntarily take on the initiative to address a problem or implement a new program." Bond further stated, "Although they have no official positional authority, they derive their respect and influence from their expertise and experience" (p. 287).

Metzgar (2008) also identified teacher expertise as an important factor for teacher leader development. Teacher expertise is based on the demonstrated instructional abilities exhibited in the classroom. Silva, Gimbert \& Nolan (2000) point to the fact that the level of expertise a teacher exhibits in the classroom is influential to teacher leader development. Teacher quality is dependent on knowledge and the skillful act of teaching (Szabo, 2009). When the art of teaching is skillfully meshed with the science of teaching, the perceptions of others regarding their abilities are enhanced (Isbell \& Szabo, 2015). Snell and Swanson (2000) also stressed that "teaching expertise is another mark of a teacher leader who is an exemplar in the classroom" (p19).

The level and quality of opportunities given for professional development, formal job embedded collaborative activities, as well as activities beyond the classroom are attributed to the degree the school organization empowers teacher leader development. The role of organizational empowerment plays a significant role in teacher leadership development and practice. The development of teacher leadership is enhanced when school organizations provide support to teachers through the availability of resources and materials, collaborative professional activities, and the opportunity to improve teacher practice through meaningful professional development activities (Danielson, 2007; Haury, 2001).

DuFour (2010), in writing about the challenges facing education today and the need to prepare educational leaders (teachers) to meet those challenges, indicated the tasks of school organizations is to "assist their teachers in acquiring the knowledge and skills necessary to solve difficult problems facing schools today.... and to also provide their teachers with the capacity to meet such challenges as will arise in the future" (p.7). The role of organizational 
empowerment is to establish formal vehicles within the school community which allow for, encourage, facilitate, and celebrate teacher involvement and leadership.

Passion, vision, and self-reflection describe different aspects of behavioral leadership characteristics. Passion, vision and self-reflection may be experienced individually, apart from one another, or in an interactive relationship. For example, passionate inquiry, coupled with self-reflection allows teacher leaders to push to their limits (Reason \& Reason, 2007). DuFour (2010) often references the importance of passion, vision, and self-reflection in building strong professional learning communities in schools through the use of teacher leaders.

In their work on teacher leadership, Lieberman and Friedrich (2010) focus on the issue of teacher identity development. Linking teacher identity development to the passion a teacher has for what they do, a vision for themselves, and their ability to reflect on their actions. According to the authors, teacher transformation to leadership cannot occur until one has developed an identity. By advocating for students, through involvement in a number of school and community based activities, teacher efficacy is practiced and continually developed. Clearly learning to lead is a multi-layered experience in terms of teacher leader development.

Interestingly, this developmental process is often hindered by the negative perceptions teachers have of themselves as leaders, which often occur early in their professional careers. LeBlanc and Shelton (1997) support this position when they state "strangely enough, teacher leadership is also handicapped by teacher leaders themselves, who simply fail to perceive themselves as leaders" (p. 34). The process of learning to lead is determined in part by the individual's own self-awareness as a leader.

\section{Research Questions}

Based on the above review of the literature, three important questions associated with teacher leader development emerged and subsequently guided this inquiry:

1) Do teacher leaders draw upon one primary influence to promote their leadership growth?

2) Do teacher leaders benefit from a "blend" of leadership factors to help develop their leadership growth?

3) When did research participants begin to view themselves as teacher leaders?

\section{Methodology}

This qualitative study used grounded theory methods (Krathwohl, 2009) to generate theories regarding the process and factors involved in leadership development. Data were collected from six participants who were graduate students in an educational leadership program. Data sources included interviews, school documents and survey results which were coded and triangulated in order to determine themes and patterns. The following categories were used as a guide: 1) professional development, 2) student advocacy, 3) job-embedded collaboration 4) organizational empowerment, 5) teacher expertise, 6) passion, 7) vision and 8) self-reflection. 
All data were triangulated in order to determine themes and patterns across and within sources.

This research employed a small sample of six teachers who were pursuing leadership roles and were identified as teacher leaders within their respective schools. For the purposes of this study participants are referred to as Teacher Leader Participants (TLP). Participants were volunteers from a graduate educational leadership program at a mid-sized northeastern state university. All of the participants were licensed teachers either pursuing an advanced degree in K-12 school leadership or enrolled in a supervisory endorsement program.

The interview protocol (Appendix 1) consisted of a series of questions designed to elicit teacher leader participants' (TLP) perceptions on their experiences as they evolved into their roles as leaders. A total of six TLPs were interviewed in four sessions. During the interview, participants were presented a series of questions aligned to eight major areas of leadership development previously discussed. In addition, responses to additional questions provided demographic information. Pseudonyms were assigned to each teacher and related audio recordings labeled and transcribed. Individual interviews were scheduled for 90 minutes. The questions asked were open ended to help facilitate substantive discussions around identified topics. Interviewees were asked the same questions in the same order at each session.

Candidates, seeking their Masters in Educational Leadership at this U.S. northeastern state university, are required to develop and maintain a Personal Leadership Plan (PLP) throughout the duration of their graduate program. The PLP consists of both long- and short-range career goals, a personal analysis of leadership style, and a self-assessment of the candidate's strengths and areas needing improvement. The PLP provided the researchers with an excellent source of information to cross reference candidates' responses to both their interviews and surveys. Candidates' personal reflections on the above themes were coded through the assignment of descriptive words or phrase to each leadership category in accordance with Krathwohl's (2009) methods. A chart detailing the results of each leadership factor on teacher leader behavior is listed below. (See Figure 1 Leadership Factors)

TLPs were given a survey to gain a broader and deeper understanding of their individual perspectives. The survey consisted of six questions which were aligned to the research questions posed in the study. The survey was administered several months after the initial series of interviews. The survey was sent to research participants by e-mail and returned in kind. Where necessary, a follow-up phone call was made to individuals to clarify a particular response (See Appendix 2).

\section{Results}

The results were derived from the analysis of three data sources: 1) interview questions, 2) survey questions, and 3) leadership factors derived from candidates' PLPs. The findings from the analysis were used to respond to each of the research questions. 


\section{Macrothink}

5.1 Research Question 1: Do teacher leaders draw upon one primary influence to promote their leadership growth?

Research question 1 examined the eight factors associated with teacher leader development to determine the level of importance participants placed on each factor. Interview questions elicited participants' self-perceptions regarding their attraction to leadership, reasons others began to view them as leaders, key factors which prepared them for leadership roles, influences of professional relationships on their experiences, and the development of their self-perceptions of their leadership abilities.

School documents consisting of candidates' PLPs show specific teacher activities which were carried out by participants in their schools. Candidates' personal reflections on those activities were coded and recorded through the assignment of descriptive words or phrase to each leadership factor (Krathwohl, 2009). The influence of those factors on teacher leader behavior are shown in the Figure 1 below. The factors of self-refection (78\%), student-advocacy (74\%), teacher expertise (44\%), passion (32\%), and vision $(31 \%)$ were identified as the most influential in contributing to teacher leader development.

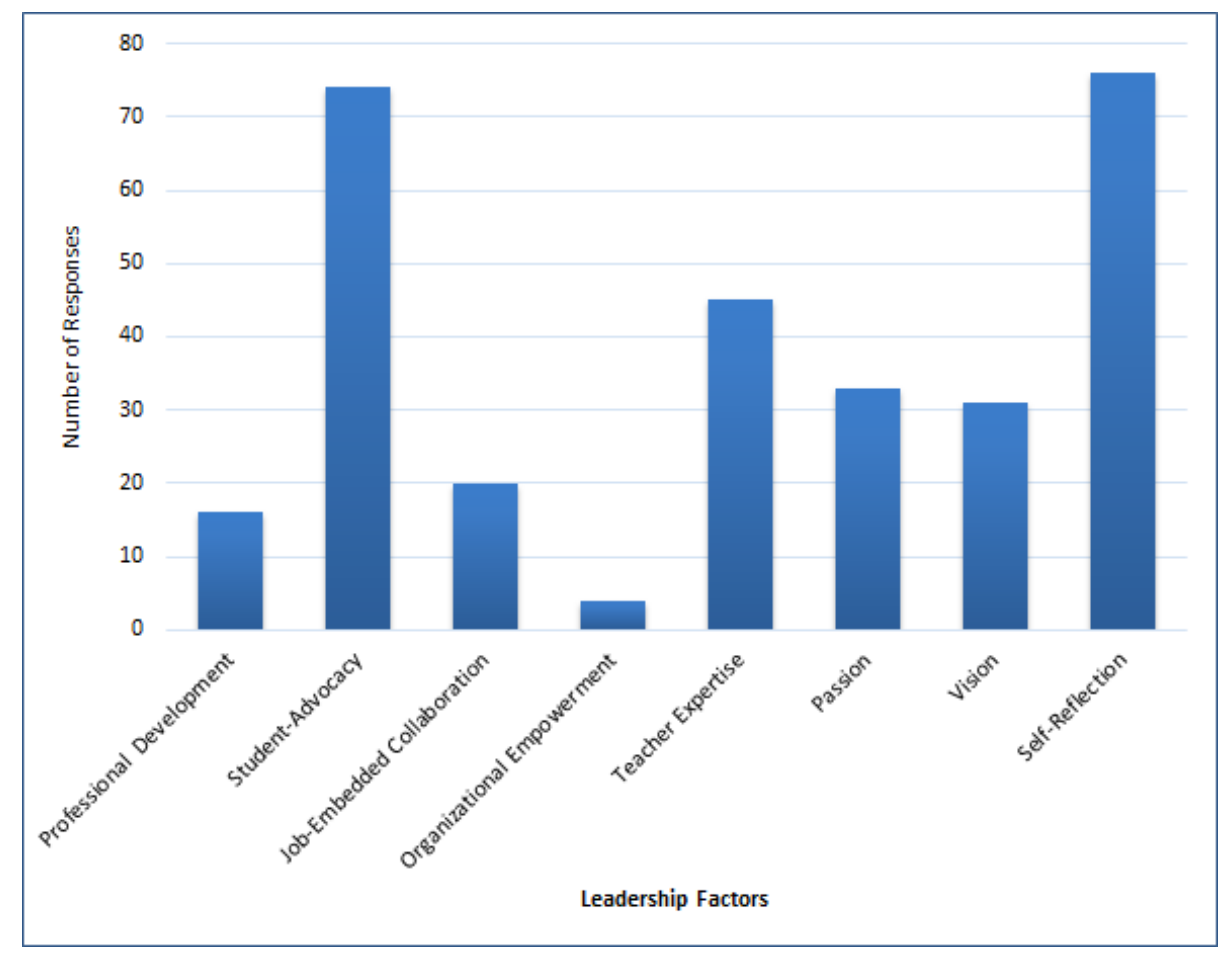

Figure 1. Leadership Factors

Leadership factors were derived from a review of leadership candidates' Personal Leadership Plans (PLPs).

These results shown in Figure 1 demonstrate the importance of the individual factor of self-reflection which address those personal introspective feelings and beliefs which participants identified as important to their leadership development. 
Additionally, in interviews all TLPs (6 of 6) viewed self-reflection as vital to their current and future success as teacher leaders. Participants identified a range of reasons for the importance of self-reflection:

- Susan attributed self-reflection as helping her recognize and understand the leadership qualities in herself.

- George indicated that he is constantly self-reflecting about various aspects of his professional activities, career and relationships with others (fellow teachers, students, staff members, parents or community members). "Personal reflection is instrumental to one's leadership role."

- Diane believes reflection transcends the teachers work in the classroom and is a key element to the school and community [relationship]. She also believes in the use of reflection to improve one's strengths and weaknesses.

The significant influence of self-reflection was also supported by the activities listed by TLPs on their survey responses as well.

The Leadership Factors Figure 1 also indicates student-advocacy as a strong factor which influences teacher leader development. Student-advocacy is a multi-dimensional factor involving the behaviors exhibited by teacher leaders, their relevant experiences working with and for students, their self-perceptions, and the transformative actions they develop as they work toward student development.

Table1. Summary of interview responses related to the factor of student advocacy.

\begin{tabular}{|l|l|}
\hline Behavioral Characteristics & Professional Experiences \\
\hline $\begin{array}{l}\text { Demonstrating a passion for teaching and } \\
\text { other student related activities not aligned to } \\
\text { classroom instruction. }\end{array}$ & $\begin{array}{l}\text { Resulted in positive recognition by } \\
\text { administrative leadership for their job } \\
\text { performance. }\end{array}$ \\
\hline $\begin{array}{l}\text { Developing positive relationships with } \\
\text { students, faculty and staff. }\end{array}$ & $\begin{array}{l}\text { Resulted in receiving recognition by fellow } \\
\text { faculty members, staff, and students for the } \\
\text { work that they do. }\end{array}$ \\
\hline $\begin{array}{l}\text { Demonstrating a willingness to work } \\
\text { collaboratively with others on teacher and } \\
\text { student activities. }\end{array}$ & $\begin{array}{l}\text { Resulted in being assigned additional tasks } \\
\text { which carried with it greater responsibilities. }\end{array}$ \\
\hline $\begin{array}{l}\text { Showing initiative by seeking out tasks to } \\
\text { perform which prove beneficial to the school } \\
\text { community. }\end{array}$ & $\begin{array}{l}\text { Resulted in participant being recognized in } \\
\text { the larger community in a positive light. }\end{array}$ \\
\hline $\begin{array}{l}\text { Taking an active part in the mission } \\
\text { objectives of the school for student } \\
\text { improvement. }\end{array}$ & $\begin{array}{l}\text { Resulted in being asked by administrative } \\
\text { leadership to serve in a mentorship role with } \\
\text { new teachers. }\end{array}$ \\
\hline $\begin{array}{l}\text { Taking the initiative to start a program in } \\
\text { school which benefited a segment of the } \\
\text { student population. }\end{array}$ & $\begin{array}{l}\text { Resulted in administrative recognition and } \\
\text { fellow teachers and staff members } \\
\text { volunteering to assist in helping. }\end{array}$ \\
\hline
\end{tabular}


Table 1 represents participant responses to questions asked during interviews regarding behavioral characteristics and professional experiences associated with student-advocacy. The left hand column reflects the behavior exhibited by individual study participants while performing their job responsibilities, while the right hand column indicates the resultant professional experiences gained because of their leadership behavior.

In interview responses, of all participants (6 of 6) also positively identified reflection, self-perception and transformative actions in their answers, as part of their leadership development experiences working with students. Participants also identified their relevant experiences as teachers, leading to developing confidence in what they were called upon to do. Therefore analysis of participant responses supports the important role student-advocacy plays in the leadership development process.

Teacher expertise reflects the instructional abilities of the teacher in the classroom and their effectiveness in carrying out assigned or non-assigned tasks. Participant responses to interview questions indicated teacher expertise as an important factor of leadership development. Two key elements were identified as important to the recognition of the expertise of the teacher: behavioral characteristics and specific school-related activities. Participants' responses suggested the following behavioral characteristics: a) the importance of exhibiting a passion for teaching, b) exhibiting positive interactions with students, staff and community, as well as c) demonstrating a willingness to work with others. Participants consistently repeated the above mentioned influences in their Personal Leadership Plans and in their responses to the survey as well. Anna reported, "I enjoy interaction with the students, the families, the parents and the school community, the staff, so I would say interaction, you know, not only with the children but with the adults as well."

Respondents also targeted specific school-related activities leading to the recognition of teacher expertise. Examples of such actions and activities included: a) effectiveness in designing and implementing lesson plans, b) working with children in activities beyond the classroom, c) modeling lessons for other teachers, d) participating in those activities designed to develop and improve one's knowledge of teaching, and e) participating in curriculum development. Participant responses to interview questions were consistent with the reflections of candidates in their Personal Leadership Plans and survey responses. Robin stated "I'm very creative, so the planning and implementing of lessons is something that I enjoy."

All of the above appear to support the premise that teacher expertise is composed of more than the teacher's ability to deliver instruction. Communication, interrelationships with the larger school community, the ability to accomplish tasks beyond the realm of the classroom, and participant personal beliefs and observations, are all factors associated with teacher expertise. Based upon participant responses to their interview questions, surveys and PLP reflections, the factor of teacher expertise is best viewed in more global terms.

Teacher leaders also expressed a strong belief in the importance of being passionate about what they do; "as a teacher you have to love what you are doing in your relationship with kids and parents", [in speaking of key factors which prepared this individual for leadership] "was the drive to be the best I could be, a passion for teaching and the ability to enthuse 
others with that passion." The influence of those strong personal introspective feelings and beliefs were still present in TLP's during interviews.

The importance of vision to TLPs was best exemplified by their responses to interview question 8, "What attracted you to the role of leadership?" TLPs identified the chance to advocate for others (students) as a key reason for seeking a leadership role (5 of 6 respondents). For example, teacher leaders stated the "chance to advocate more effectively for students" from a leadership role as important factor that attracted them to leadership. One teacher leader envisioned "helping to improve the image of the teaching profession" as reason for wanting to be a teacher leader. One respondent indicated he enjoyed teaching, but the climate in education, especially criticisms teachers had received, lead him to wanting to impact the profession positively with integrity and honesty. He felt the best way to accomplish his tasks was through advocating from a position of leadership. Others indicated "wanting to make a difference in people's lives" as important.

Based upon teacher leader responses, it would seem the leadership factors of self-reflection; student-advocacy, teacher expertise, passion, and vision are highly influential in the development of teacher leaders and represent a higher order of factors. Participant responses to those five (of eight) factors aligning to question 1 demonstrate the importance of each factor in teacher leadership development. In addition, those leadership factors blend together as participants move toward their stated objectives and goals. However in this blending process the teachers' ability to fill what is viewed as traditional teaching responsibilities inside the classroom (the effective delivery of instruction), and student related activities associated with the school, combined with their ability to self-reflect on their objectives and goals is powerful and holds sway over other factors present in question 1.

Table 2. Results research question 1

\begin{tabular}{|l|l|l|l|}
\hline $\begin{array}{l}\text { Research } \\
\text { Question 1 }\end{array}$ & Leadership Factors & $\begin{array}{l}\text { Interview } \\
\text { Questions }\end{array}$ & Outcome/Findings \\
\hline $\begin{array}{l}\text { Do teacher leaders } \\
\text { draw upon one } \\
\text { primary influence } \\
\text { to promote their } \\
\text { leadership growth? }\end{array}$ & $\bullet \begin{array}{l}\text { - Teacher Expertise } \\
\text { - Student-Advocacy }\end{array}$ & $\begin{array}{l}1,5,6,8,9, \\
12,14,15,\end{array}$ & $\begin{array}{l}\text { Yes, teacher leadership draws } \\
\text { upon the leadership factor of } \\
\text { teacher expertise (6 of 6 } \\
\text { respondents), and self-reflection } \\
(6 \text { of 6). }\end{array}$ \\
\hline
\end{tabular}

Table 2 provides a visual representation of the relationship between the question, the leadership factor, the aligned interview question, and the results.

5.2 Research Question 2: Do teacher leaders benefit from a "blend" of leadership factors to help develop their leadership growth?

As the analysis of teacher responses to question 1 demonstrated, leadership factors are often combined as teachers move toward leadership roles. Therefore, a number of interview 
questions aligned to the leadership factor for question 1 were also applicable to question 2 . Teacher leader responses to interview questions and survey responses provide evidence of how teacher leaders benefit from factors blending together in the leadership development process. Three examples are detailed.

\subsubsection{Teacher Expertise and Student Advocacy}

Pat indicated that it was not one single event, person, or reason which attracted her to leadership, but her interest in the leadership role evolved slowly over time. Pat referenced the fact that she had taught for 16 years and she was ready. Her readiness was predicated on the relevant professional experiences she encountered during her tenure as a classroom teacher (e.g. experiences like curriculum work, developing and improving upon her teaching, experiencing and learning the IEP process, and her strong relationships with students). She developed strong ties to the community as her leadership potential developed through a process of slow, yet continuous change.

\subsubsection{Student-Advocacy, Passion, Vision}

Robin always felt herself to be a teacher leader as far back as when she began her career. This was due in large part to the success she enjoyed with initiatives she began as a new teacher with her students in the school.

\subsubsection{Teacher Expertise and Vision}

Anna noted that at first the administration started taking note of her instructional performance. From that point she moved to participating as a mentor for both younger and seasoned teachers. Often when a new initiative was implemented, she would be called upon to turn-key it to staff.

A review of the researchers' analyses of teacher leader statements link all respondent experiences (6 of 6) to leadership factors of teacher expertise, student-advocacy, passion, vision and self-reflection. Therefore teacher leader responses to question 2 further support our premise about the inter-relationship (blending) which exists between leadership factors that influence participant movement toward leadership roles.

Table 3. Results research question 2

\begin{tabular}{|c|c|c|c|}
\hline $\begin{array}{l}\text { Research } \\
\text { Question } 2\end{array}$ & Leadership Factors & $\begin{array}{l}\text { Interview } \\
\text { Questions }\end{array}$ & Outcome/Findings \\
\hline $\begin{array}{l}\text { Do teacher leaders } \\
\text { benefit from a } \\
\text { "blend" of } \\
\text { leadership factors } \\
\text { to help develop } \\
\text { their leadership } \\
\text { growth? }\end{array}$ & $\begin{array}{l}\text { - } \text { Teacher Expertise } \\
\text { - Student-Advocacy } \\
\text { - Self-Reflection } \\
\text { - Passion } \\
\text { - Vision }\end{array}$ & $\begin{array}{l}1,5,6,8,9 \\
12,14,15 \\
18\end{array}$ & $\begin{array}{l}\text { Yes, teacher leaders both } \\
\text { experience and benefit from the } \\
\text { inter-relationships which exist } \\
\text { between key leadership factors } \\
\text { ( } 6 \text { of } 6 \text { respondents agree). }\end{array}$ \\
\hline
\end{tabular}

Table 3 provides a visual representation of the relationship between the question, the leadership factors, the aligned interview questions, and the results. 
5.3 Research Question 3: When did research participants begin to view themselves as teacher leaders?

Teacher participants identified a number of different ways in which they began to perceive themselves as teacher leaders. This has become a very important question because we know from previous research conducted that teachers' self-perceptions as leaders are often difficult to achieve (LeBlanc \& Shelton, 1997). Further, viewing oneself in a positive light as a leader forms the foundation for subsequent behaviors, actions, and mental focus necessary toward becoming a teacher leader. The following are participant observations about their own perceptions regarding their leadership abilities. In response to the question, "Does the term leadership apply to the work that you do in your schools?"

- Anna replied, "Yes, definitely. Everyone is a teacher leader in some way. Your leadership role is shaped by how students view you and the expectations they have of you."

- Diane stated, "Yes, as a Literacy Coach", assigned by administration to turn-key information to her teachers.

- Robin replied, "Yes, I was chosen as a grade level chairperson by my peers."

- Pat indicated "Yes, absolutely!" the key to what she does, is taking the initiative to approach others with relevant questions and also bring potential solutions to problems.

In responding to a question about the influence their personal vision may have had on their becoming a teacher leader, respondents reported:

- Susan felt her personal vision helped her focus on her professional goals and objectives, giving her confidence in herself that she is a teacher leader.

- Diane indicated that personal vision provided her with clarity on her beliefs on her views in life and her professional goals.

- Clearly the self-perceptions (from reflection) teachers develop about themselves occurs in different ways and takes different forms.

Table 4. Results research question 3

\begin{tabular}{|c|c|c|c|}
\hline $\begin{array}{l}\text { Research } \\
\text { Question } 3\end{array}$ & Leadership Factors & $\begin{array}{l}\text { Interview } \\
\text { Questions }\end{array}$ & Outcome/Findings \\
\hline $\begin{array}{l}\text { When did } \\
\text { research } \\
\text { participants } \\
\text { begin to view } \\
\text { themselves as } \\
\text { teacher leaders? }\end{array}$ & $\begin{array}{ll}\text { - } & \text { Self-Reflection } \\
\text { - } & \text { Student-Advocacy } \\
\text { - } & \text { Job Embedded } \\
& \text { Collaboration with } \\
\text { Peers } \\
\text { - } \text { Professional } \\
\text { - } \text { Development } \\
\text { - } \text { Passion } \\
\text { - } \text { Organizational } \\
\text { Empowerment }\end{array}$ & $\begin{array}{l}5,6,8, \\
11,12, \\
14, \\
17,\end{array}$ & $\begin{array}{l}\text { The majority of respondents ( } 5 \text { of } \\
\text { 6) indicated Self-Perception as a } \\
\text { leader began with recognition } \\
\text { from others. Their perceptions of } \\
\text { our participants being influenced } \\
\text { by their performance in the key } \\
\text { leadership factors. }\end{array}$ \\
\hline
\end{tabular}


Table 4 provides a visual representation of the relationship between question 3 , the leadership factors, the aligned interview questions, and the results.

\section{Summary/Conclusions}

From the analysis of our research data on teacher leadership development, we have drawn several conclusions from our findings. Teacher leadership development is dependent upon several key leadership factors which are inter-related and interact with each other as part of a blended teacher leadership developmental process. Although certain factors may have strong influence over a teacher's development into a leadership role (e.g. demonstrated teacher expertise), it would be very difficult to have a leadership development process without the influence, or impact of other leadership factors. Blending a combination of leadership factors is necessary and non-negotiable in the developmental process of teacher leaders. However, some leadership factors are more foundational than others. For example, all study participants began their journey toward a leadership role by being recognized by others (e.g. peers, administration, students and parents) for their work done in the classroom. Recognition was gained by the teachers' ability to demonstrate effectiveness in carrying out traditional instructional responsibilities in the classroom.

Time, self-reflection, student-advocacy and teacher expertise appear to be key elements in teacher leader development, allowing the opportunities for leadership activities to materialize in this way both formal and informal opportunities for leadership were made available. Moving from the role of teacher to teacher leader is often a slow, measured process involving the accumulation of relevant experiences over time. The teacher leadership development process is also layered, in terms of when one acquires the necessary knowledge, experiences, recognition, and self-reflection to move into a teacher leader role. Teacher leaders make effective use of self-reflection as an instrument for improving themselves (either professionally or personally) toward achieving their goal of obtaining a leadership role. In this case the act of reflection is used as a transformative vehicle for the purpose of changing behavior, viewpoints, professional direction, objectives or goals. The process of self-reflection becomes a vehicle toward self-actualization. The three factors: professional development, collaboration with peers, and organizational empowerment were not perceived by teacher leader candidates to be as influential on their leadership development as suggested by previous research (Hunzicker, 2012). These factors may actually hinder teacher leader development when minimal or absent, but they do not prevent teachers from developing as leaders.

\section{Recommendations}

Based on the findings of this preliminary inquiry regarding the key factors of teacher leadership development, we suggest the following in order to cultivate future leaders:

- Teacher leadership development programs should make effective use of early identification, support through mentorship, and time to allow selected teachers to participate in relevant experiences. 
- Teacher leader programs must link the important role of reflection as part of the leadership development process.

- Teachers should have an integral part to play in the identification process of potential teacher leaders.

- It's important to introduce the concept of leadership to perspective teacher leaders early in their careers, allowing teachers to understand the qualities of effective teacher leaders.

- As a result of the small sample size, the findings of the study cannot be generally applied to other larger populations. Rather the study can be viewed from the perspective of providing a greater understanding of how teachers are able to develop and exercise leadership coming from their specific backgrounds and within the context of the educational program they completed (Stake, 2000).

- Future studies should include a redesign of the interview and survey questions to eliminate redundancy, leading questions, and close ended questions.

\section{References}

Bond, N. (2011). Preparing pre-service teachers to become teacher leaders. The Educational Forum, 75 (4), 280-297. http://dx.doi.org/10.1080/00131725.2011.602578

Danielson, C. (2007). The many faces of leadership. Educational Leadership, 65(1), 14-19.

DuFour, R., Eaker, T., \& Many, T., (2010). Learning by doing: A handbook for professional learning communities at work. Bloomington, IN: Solution Tree Press.

Haury, D. (2001). Cultivating Leadership among science and mathematics teachers. Eric Digest. Columbus OH: Eric Clearinghouse for Science, Mathematics, and Environmental Education.

Hunzicker, J. (2012). Professional development and job-embedded collaboration: How teachers learn to exercise leadership. Professional Development in Education, 38(2), 267-289. http://dx.doi.org/10.1080/19415257.2012.657870

Isbell, L., \& Szabo, S. (2015) Assessment: Teacher efficacy and response to intervention. The Delta Kappa Gamma Bulletin, International Journal for Professional Educator, (81-2) p.41-46.

Krathwohl, D. (2009). Methods of Educational and Social Science Research: The Logic of Methods. Long Grove, IL: Waveland Press, Inc.

LeBlanc, P., \& Shelton, M. M. (1997). Teacher leadership: The needs of teachers. Action in Teacher Education, 19(3), 32-48. http://dx.doi.org/10.1080/01626620.1997.10462877

Lieberman, A., \& Friedrich, L. D. (2010). How teachers become leaders: Learning from practice and research. New York: Teachers College Press.

Nesbit, C. R., DiBiase, W. J., Miller, A. C., \& Wallace, J. D. (2001). In their own words: What science and mathematics teacher leaders say are important aspects of professional development. Columbus, $\mathrm{OH}$ : Eric Clearinghouse for Science, Mathematics, and 
Environmental Education.

Metzgar, V. H. (2008). Development of an observationally anchored rating scale to assess the frequency of teacher leadership behaviors in schools (Ed.D. Dissertation). Peabody College for Teachers of Vanderbilt University.

Reason, C. \& Reason, L. (2007). Asking the right questions. Educational Leadership, 65(1), 36-40.

Silva, D. Y., Gimbert, B., \& Nolan, J. (2000). Sliding the doors: Locking and unlocking possibilities for teacher leadership. Teachers College Record, 102, 779-804.

Snell, J., \& Swanson, J. (2000, April 24-28). The essential knowledge and skills of teacher leaders: A search for a conceptual framework. Paper presented at the annual meeting of the American Educational Research Association, New Orleans, LA

Stake, R. E. (2000). Case studies. In: N.K. Denzin and Y.S. Lincoln, eds. Handbook of qualitative research ( $\left.2^{\text {nd }} \mathrm{ed}\right)$. Thousand Oaks, CA: Sage, 435-454.

Szabo, S. (2009). Rekindling the art of teaching: Engaging teachers' hearts and minds in the age of accountability. English in Texas, 38(1), 59-72.

\section{Appendixes}

Appendix 1 Interview Questions:

1. How long have you been teaching?

2. What subject area and grade level do you teach?

3.Have you obtained your Supervisory endorsement? If so when?

4. What three things do you enjoy most about teaching

5. Can you define what teacher leadership means to you?

6. Are there specific characteristics, behaviors, or activities which indicate teacher leadership?

7. Does the term leadership apply to the work that you do in your school? Why, why not?

8. What attracted you to the role of leadership?

9. What were some of the reasons others (teachers, administrators and students) began viewing you as a teacher leader?

10. What hurdles have you encountered on your career path?

11. Was personal reflection important or not important to your growth into a leadership role? Why, why not?

12. Upon reflection, what were some of the key factors which prepared you for a teacher leadership role?

13. Upon reflection, what role did your personal vision play on you becoming a teacher leader?

14. How influential were the professional relationships established with your colleagues, important to your filling a teacher leader's role in school? 


\section{Macrothink}

15. What has been most influential in developing your view of yourself in a leadership capacity, motivating you to take the steps necessary toward filling a leadership role, allowing you to maintain your diligence toward reaching your leadership goals?

16. What role has professional development programs played in your leadership development?

17. Did you have the opportunity for collaboration with your peers on the job? If so, how influential were those collaborative opportunities in your development as a teacher leader?

18. If you had your choice, what would you prioritize if you were developing a leadership program for teachers?

Appendix 2. An Examination of the Various Ways Teachers Become Leaders Survey

1. From the following list of leadership factors indicate which one, or more were the most influential to your growth into a leadership role. Circle all those which apply.

a. Teacher expertise

b. Exposure to professional development activities

c. Job embedded collaboration with peers

d. Student-advocacy

e. Organizational empowerment

f. Personal passion

g. Vision

h. Self-reflection

2. From the following list of leadership factors identify those which were most compatible (if any) with one another in your leadership development. Circle all those which apply.

a. Teacher expertise

b. Exposure to professional development activities

c. Job embedded collaboration with peers

d. Student-advocacy

e. Organizational empowerment

f. Personal passion

g. Vision

h.Self-reflection

3. From the following list of leadership factors what must a teacher leader possess, more then a teacher? Circle all those which apply.

a. Teacher expertise

b. Exposure to professional development activities

c. Job embedded collaboration with peers

d. Self-advocacy

e. Organizational empowerment

f. Personal passion

g. Vision

h. Self-reflection 
4. From the following list which experiences were the most influential in helping to shape your perception of yourself as a teacher leader? Circle all those which apply.

The expressed viewpoints of others (teachers, students, administrators) with regard to your abilities as a teacher.

a.Participation in school related activities.

b.Identified and chosen by your peers for a leadership role.

c.Developing self-confidence as the result of achieving a goal, or completing an important task.

d. Your personal and professional vision.

e.Administrative assigned tasks for the purpose of providing support for teachers.

f. Taking the initiative to approach others to help solve a problem in the classroom, or building.

5. The range of years listed below represent time spent teaching in the classroom. From the list, which time period would you identify as having experienced the most significant growth in your teaching and classroom management skills?
a. $1-3$
b. $4-7$
c. $8-11$
d. $12-15$
e.Over 15

6. The range of years listed below represent time spent teaching in the classroom. From the list, which time period would you identify as having experienced the most significant growth in your leadership abilities?
a. 1-3
b. $4-7$
c. $8-11$
d. $12-15$
e.Over 15

\section{Copyright Disclaimer}

Copyright reserved by the author(s).

This article is an open-access article distributed under the terms and conditions of the Creative Commons Attribution license (http://creativecommons.org/licenses/by/3.0/). 